\title{
Family Education Through the Lens of Metropolitan Andrey Sheptytsky's Views
}

Olena Nevmerzhytska / e-mail: nhelen750@ gmail.com

Department of General Pedagogy and Preschool Education, Faculty of Psychology, Pedagogy and Social Work, Drohobych Ivan Franko State Pedagogical University, Drohobych, Ukraine

Myroslav Pahuta / e-mail: miroslav06@ rambler.ru

Department of Technological and Professional Education, Educational and Scientific Institute of Physics, Mathematics, Economy and Innovative Technologies, Drohobych Ivan Franko State Pedagogical University, D rohobych, Ukraine

Nevmerzhytska, 0. - Pahuta M. (2020). Family Education Through the Lens of Metropolitan Andrey Sheptytsky's Views. Czech-polish historical and pedagogical journal11/2, 153-162.

https://doi.org/10.5817/cphpj-2020-029

In the current context, we are confronted with controversial views on the family and family education, which are caused by the complex conditions in which the family organism must function. Therefore, it is important to study the views of the past eminent figures on family education for the purposes of predicting the ways of development of the modern family. Andrey Sheptytsky, the head of the Ukrainian Greek Catholic Church, viewed the role of the family and the peculiarities of its educational function in the context of the neo-Thomism philosophy, but the characteristic feature of his views is democracy. He professed the democratism of family relations between spouses, as well as between parents and children. He expressed his views on the main goals of family education, its content and methods, which remain largely relevant today.

Key words: family; family education; parents; children; Metropolitan Andrey Sheptytsky

The present state of development of human civilization is characterized by rapid changes and transformations. The processes of globalization, integration, and informatization greatly change the picture of the world and affect all aspects of our lives, as we must adapt quickly and flexibly to the new conditions of life. Environmental, economic and social disasters continue to disturb humanity. At the beginning of the $21^{\text {st }}$ century, humankind is faced with many serious challenges, such as overcoming poverty, filling food and drinking shortages in several countries, combating serious diseases which are turning into epidemics, finding ways to restore ecological balance, etc. Today in the center of Europe there is an ongoing military conflict which has resulted in thousands of killed and wounded people, as well as millions of refugees. 
In a situation of confusion and alienation, everyone is looking for a place where they can rest and at least temporarily forget about their problems. Such place can and should be found within a family circle. This may be the parent family in whichthe person grew up, or it may be their spouse and/or children.

The role of the family in personal development is difficult to overestimate. It is the first environment children encounter in their lives, a micro-model of society in which they learn about social relations and get to know the world around them.In this context, it should be noted that the first influences on the individual are always the most profound and lasting, and therefore it is obvious that the demandson the modern family are extremely high.

However, modern families are often in crisis because they are also influenced bythe economic and sociocultural situation, state family policy, etc. These influencesaffect their lives, stability, performance of different functions, including educational. A ccording to Tetiana A leksejenko, ${ }^{1}$ in recent decades the modern family has undergone a number of transformations, which are divided into following groups:

1) structural. These include an increase in the number of single-parent families and mortality of parents, as well as the decrease in the number of children infamilies, formation of restructured families, etc.;

2) motivational, which imply an increase in the motivation of parents to change their role behavior and fulfill their parental responsibilities. However, it should be noted that despite the motivation, it is not always possible to successfully carry out the educational function in the context of constant labour migration of the population, in particular, of one or both parents;

3) value orientations, which are caused by the change of ideal perception of parents and children, family, hierarchy of values, ways of family life and upbringing, stereotypes regarding family roles, development of new family traditions;

4) interpersonal, embodied in the changing relationships between parents and children, which are increasingly becoming a sign of democratization, partnership and competitiveness;

5) procedural, characterized by ambiguous quality of carrying out family functions and roles;

6) subcultural, which are a consequence of the influence of globalization processes, the media and the Internet on the value orientations of the family and the behavior patterns of parents and children, the way of life of the familyand the formation of indirect influences in education.

In modern democratic societies, views on family and gender roles of family members are changing. There is no clear distinction between male or female work,

${ }^{1}$ Aljeksjenko T. (2016). Tendenciji transformaciji vykhovnoji funkciji simji ta osnovni 
priorytety sučasnoji deržavnoji polityky u zakhysti prav dytyny v Ukrajini. Teoretykometodyčni problemy vykhovannja ditej ta učnivśkoji molodi. Vyp. 20, Kn. 1, p. 27. 
both father and mother make equal contributions to the upbringing of children. This state of affairs seems obvious and correct. However, often it does not save the family from falling apart, nor does it affect the desire of young people to start families. Today we face such phenomena as the unwillingness to marry, the emergence of new forms of marriage, or the "child-free" lifestyle. All these are phenomena of our time that depend on the sociopolitical and cultural conditions of the present.

According to Ukrainian educator Omelian Vyshnevskyi, among the factors that influence the stability of the modern family are liberalization of views on sex life, light-hearted attitude to marital treason, conciliation with the facts of prostitution and pornography, perception of family conflicts, quarrels and divorces as a norm, a negative attitude towards family life resulting from the negative experience of a mother/father, or a child's own experience in a conflict- prone family, consumer installations, material difficulties, displacement of social roles in traditional relations between men and women (the man is feminized and the woman is masculinized, which means a reassessment of demands and mutualcomplaints), etc. ${ }^{2}$

However, the question whether the way of reorienting one's views on the modern family is right or worthwhile remains rhetorical. We cannot predict the future, but we can turn to the historical experience, views of the past eminent figures on the issues of family education of children and youth.

In this context, we shall turn to the views of Metropolitan Andrey Sheptytsky (1865-1944), a prominent religious figure of the late $19^{\text {th }}$ and early $20^{\text {th }}$ century, head of the Ukrainian Greek Catholic Church, whose activity was hailed as "visionary and thorough", "heroic and apostolic" Pope John Paul II.

Metropolitan's activity was diverse. It is safe to say that Andrey Sheptytsky actively participated not only in pastoral (religious) activity, but also realized himself in social, political, educational and pedagogical work. $\mathrm{He}$ paid considerable attention to the education of the Greek-Catholic clergy, was interested in the problems of education and supported preschool, folk, secondary, vocational and higher education, promoted the development of out-of-school upbringing of Ukrainian youth (in particular the activities of youth organizations of Christian and patriotic education), financed numerous educational and pedagogical publications, contributed to the development of Ukrainian science.

Metropolitan Andrey left behind a rich written heritage: monographs, epistles, decrees, letters raising various issues (building a socially just state, meeting the economic, cultural and social needs of the individual and the nation as a whole, raising children and young people, etc.). Obviously, they are addressed from the point

2 Vyšnevśkyj O. I. (2003). Teoretyčni osnovy sučasnoji ukrajinśkoji pedahohiky. Drohobyč, 
Kolo, p. 299.

3 Ivan Pavlo II. Propovid’ pid čas Beatyfikacijnoji Božestvennoji Liturhiji. L’viv, 27 červnja 2001 r. 
of view of Christian doctrine, but they can also serve as a reference point for themodern non-religious person as they are the em bodiment of age-old human wisdom. Sheptytsky supported the democratization of social life, applauding its new values which appeared at the turn of the $19^{\text {th }}$ and $20^{\text {th }}$ centuries.

He drawsattention to the changes in the relationships between people who begin to rely onthe virtues of justice and love, the parental power which replaced tyranny, thedisappearance of slavery and the actualization of such

values as understandingand equality of people, the transformation of the limitless right of a man overa woman and the father over the children into the laws of family love. "Everythingin the world is slowly changing for the better. B oth government and law, customsand human rules, as well as international relations and family life... Humanity... is returning to moral health and social order". ${ }^{4}$

Metropolitan believed that the family is an organism created by the will andmind of an individual in accordance with the forces of nature and its laws. Heconsiders community to be the same organism, as it is a group of people united by a shared settlement area and connected not only by the neighborhood butalso by the commonality of needs and interests. Family and community are a kind ofprotoplasm, the primordial cells that make up the human society, and both of these organizations will grow stronger if they learn to respect nature and its law s. ${ }^{5}$ In the early $20^{\text {th }}$ century, back when he

was still a bishop of the Stanislav Diocese, Andrey Sheptytsky wrote a pastoral epistle entitled "The Christian Family", 6 in which he drew attention

to various aspects of family life, viewing thefamily as the basis of order and future. This is Sheptytsky's first pastoral epistle, and it is notew orthy that it addresses precisely the problems of the family, whichhe considered to be the

basis of human life, relating it to the future of the wholehumankind, and therefore its development and progress. He wrote: “...thehappiness and moral value of each person in particular and of the humankind overall, and to a greater extent its future, depends on whether the root of social life and the area of human life which keeps all of its work is healthy and strong... The future belongs to those people who consider marriage to be a holy thing, to whomfamily life is pure and holy! And among such people it is easy to find order and

power. Such people earn their welfare with elemental power". ${ }^{7}$

Marriage is a moral obligation. Therefore, it imposes certain moral duties onboth sides and puts the spouses on a mutually dependent basis. In fact, this moral

${ }^{4}$ Pastyrśke poslannja Mytropolyta Andreja do dukhovenstva i virnykh «Na hrani dvokh vikiv» (2007). In Šeptydkyj Andrej. Pastyrśki poslannja 1899-1914 rr. L'viv, Vydavnyctvo «ARTOS», vol. 1, p. 100.

5 Šeptyd'kyj A. (1989). Jak buduvaty ridnu Khatu. Ljublin, Svičado, p. 4.

$6 \quad$ Pastyrśke poslannja jepyskopa Andreja do dukhovenstva ta virnykh Stanyslavivśkoji 
jeparxiji

«Khrystyjanśka rodyna» (2007). In Šeptyćkyj Andrej. Pastyrśki poslannja 1899-1914 rr. L'viv,Vydavnyctvo «ARTOS», vol. 1, pp. 53-71.

7 Ibid., p. 58. 
obligation is the key to family stability and healthy parenting. Moreover, A ndrey Sheptytsky claimed: "... to eliminate morality from what the future of the peopledepends on would be the obvious attempt to keep people off track and underminetheir ethics. A nd the strength and happiness of the people depends on their ethics!". ${ }^{8}$ A s a bishop, A ndrey reflected on the role of each family member and wrote about the duties of the fathers "...who would be an example of Christian life, trueguardians and good life guides for their wives", mothers "...who would know wellhow to bring up their children in Christian traditions and provide help, comfort and good counsel for their husbands" and children

"... that would be the joy andglory of the parents and the beauty of their nation". ${ }^{9} \mathrm{He}$ clearly substantiated therole of both husband and wife in family life. He believed that a good wife bringshappiness to a husband, because she helps him to fulfill his duties, to enduredifficulties, as well as to "work on the upbringing of their children so they wouldgrow up to be decent people... Just like an angel, she prays daily for mercy for thewhole family, and with communion, patience and love, she settles all disputes, quarrels and

misunderstandings between the father and the children". It is the responsibility of the husband, the father of the family to work for its benefit, to educate children so they would eventually become good workers and honestpeople who would be able to cope with every day difficulties, ready to

fulfill theirduties, true Christians. "A good husband gives support, counsel, strength, help and is an example for his wife; for children, he is a guide, a teacher and a friend". ${ }^{10}$ Judging by this quote, we can safely assume that Andrey Sheptytsky adhered to the traditional view of the distribution of roles within the

family, which is obvious and not surprising. In his opinion, a father should provide his wife and children with support, be their protector and breadwinner. The mother is the keeper of thehearth who takes care of all the family members, provides help for her husband and brings up the children.

Andrey Sheptytsky emphasized the values of family life, in particular happiness, love and harmony: "Because there is no greater joy in the world thanhappiness, love and harmony in the family!". ${ }^{11}$ He especially em phasized love, which he considered to be the basis of married life, because "the love that keeps the family together gives them the kind of happiness which cannot be acquired neither with wealth nor glory or any material goods". ${ }^{12}$ He compared marital love to water

8 Ibid., pp. 56-58.

9 Ibid., p. 71.

10 Šeptyćkyj Andrej. (1911). Kanadyjskym rusynam. Žovkva, Pečatnja OO. Vasylyjan, pp. 78-79.

${ }^{11}$ Pastyrśke poslannja jepyskopa Andreja do dukhovenstva ta virnykh Stanyslavivśkoji jeparkhiji «Khrystyjanśka rodyna» (2007). In Šeptyćkyj Andrej. Pastyrśki poslannja 1899-1914 rr. L'viv, Vydavnyctvo «ARTOS», vol. 1, p. 62. 
12 Pastyrśke poslannja Mytropoyta Andreja «O supružestvi i rodyni» (2007). In Šeptyćkyj Andrej. Pastyrśki poslannja 1899-1914 rr. L'viv, Vydavnyctvo «ARTOS», vol. 1, p. 377. 
for fish and soul for a human being: "a family without love is like a body withouta soul". ${ }^{13}$ He was convinced that wherever there is love between husband and wife, where parents love children and children love parents, there will be happiness. And wherever there is true love in the family, "children will be well-bred and willgrow up in the praise of God and the good of the people". ${ }^{14}$ He also emphasized that Christian life, avoidance of quarrels, disagreements and infidelity are im portant for the happiness of spouses and children. ${ }^{15}$

The social role of the family is also to bring up children. In this regard, Andrey Sheptytsky wrote: "And imposing the duty of good upbringing on the parents, society is given an appropriate way of multiplying health and strength in such anethical atmosphere that the new generations will be able to develop their bodies and souls for the positive forces of society". ${ }^{16} \mathrm{He}$ believed that the greatest good that parents can do for their children is respectful piety, striving for honest work, protection from immorality, etc. ${ }^{17}$

Bishop Andrey Sheptytsky considered the upbringing of children to be an important duty of the parents, considering that the hearth is the first and most important school of love. He poetically claimed that parents' love and care for the child are as vital as the light of the sun, and that the first impressions they receive, such as the first word from the mother, the first lesson from the father, the first example of the parents, are the life-giving dew for the child. ${ }^{18}$

Family should implement religious, moral, labor, civil and valeological education. Religious education depends on the family atmosphere and the foundations on which the family is built. It must provide children with the knowledge of God's law and the truths of the holy faith, as well as the desire to live honestly and courteously in a Christian way. ${ }^{19}$

13 Ibid., p. 377.

14 Pastyrśke poslannja Mytropolyta Andreja do dukhovenstva ta virnykh «Najbil’ša Zapovid'» (2007). In Šeptyćkyj Andrej. Pastyrśki poslannja 1899-1914 rr. Lvviv, Vydavnyctvo «ARTOS», vol. 1, p. 136-137.

15 Pastyrśke poslannja Mytropolyta Andreja do virnykh «Pravdy Viry» (2007). In Šeptyd'kyj Andrej. Pastyrśki poslannja 1899-1914 rr. L’viv, Vydavnyctvo «ARTOS», vol. 1, p. 350.

16 Pastyrśke poslannja jepyskopa Andreja do dukhovenstva ta virnykh Stanyslavivśkoji jeparxiji

«Khrystyjanśka rodyna» (2007). In Šeptyćkyj Andrej. Pastyrśki poslannja 1899-1914 rr. L'viv,Vydavnyctvo «ARTOS», vol. 1, p. 59.

17 Pastyrśke poslannja Jepyskopa Andreja do virnykh Stanylavivśkoji jeparkhiji «Perše slovo pastyrja» (2007). In Šeptyćkyj Andrej. Pastyrśki poslannja 1899-1914 rr. Lviv, Vydavnyctvo «ARTOS», vol. 1, p. 14.

18 Pastyrśke poslannja jepyskopa Andreja do dukhovenstva ta virnykh Stanyslavivśkoji jeparkhiji «Khrystyjanśka rodyna» (2007). In Šeptyćkyj Andrej. Pastyrśki poslannja 1899-1914 rr. Lviv, Vydavnyctvo «ARTOS», vol. 1, pp. 62-63. 
19 Šeptyćkyj Andrej. (1911). Kanadyjskym rusynam. Žovkva, Pečatnja OO. Vasylyjan, p. 50. 
Similarly, social upbringing is dependent on socio-Christian foundations of family life. Its task is to educate "righteous citizens". ${ }^{20}$ Andrey Sheptytsky believed that among the social qualities that should be developed in children are such family virtues and principles as fulfilment of their duties, work for the common good, sharing of own goods and benefits with others, stability, hardship. ${ }^{21}$

According to Sheptytsky, another important task for the family is to educate a good patriot. He considered a person who loves all people, but first and foremost their family and homeland, to be a true patriot. At the same time, feelings of patriotism should not be combined with hatred. In A ndrey Sheptytsky's undersanding, the essential feature of patriotism is its effectiveness. "Someone who consciously fulfils their duties and works for the good of the nation is a betterpatriot than someone who says very much but does very little". ${ }^{22}$

The Metropolitan drew the attention of believers to the need to maintain a healthy lifestyle. He made a link between health and morality, believing that only "healthy and physically strong races can be happy". He emphasized that if parents love their children and their nation and care for their happiness and health, they must live morally instead of killing themselves and their children, and not waste physical forces of the people with immorality. He strongly condemned alcoholism among parents. He urged children to appreciate innocence and purity. The importance of moral, physical and valeological education for him was obvious, because "the people who are moral, physically strong, healthy and sober can easily gain them selves a good economic life, the opportunity to afford their very own house and become wealthy even in difficult circumstances, all because of their hard work and the grace of God". ${ }^{23}$

The Metropolitan acknowledges the educational work of parents as difficult, lengthy struggle which requires many sacrifices, "constant care and sensitive attention to the great manifestations of the child's life, so that the child would become a good citizen, conscious of all his duties towards God, family, close ones and motherland; it takes immense work for a child to become an adult, a full- fledged and inteligent citizen". ${ }^{24}$

A nother important method of education, according to Sheptytsky, was the parents' example. He emphasized that the upbringing is reflected in the family

${ }^{20}$ Protokoly zasidań L'vivśkykh arkhijeparkhial'nykh soboriv 1940-1944 rr. Protokoly zasidań pidhotovčykh ta uročystykh sesij (2000). L'viv, «Misioner», p. 295.

21 Pastyrśke poslannja Mytropolyta Andreja «Do poljakiv hreko-katolyćkoho obrjadu» (2007). In Šeptyćkyj Andrej. Pastyrśki poslannja 1899-1914 rr. L'viv, Vydavnyctvo «ARTOS», vol. 1,pp. 499-500.

22 Pastyrśke poslannja Jepyskopa Andreja do virnykh Stanyslavivśkoji jeparkhiji «Perše slovo pastyrja» (2007). In Šeptyćkyj Andrej. Pastyrśki poslannja 1899-1914 rr. L'viv, 
Vydavnyctvo

«ARTOS», vol. 1, p. 16.

23 Ibid., pp. 5-6.

24 Šeptyćkyj A. (1991). Za jednist' svjatoji viry, cerkvy i naciji, p. 20. 
school of life: “...the upbringing of your children mainly depends on what your family is like!". ${ }^{25}$

Andrey Sheptytsky defended the adherence to the principle of democratization in family education. "...parents have to teach children discipline and to develop their obedience to themselves with Christian upbringing, but not to impose that obedience so that it is annoying for children and causes them to feel angry and irritated. The mutual relationship between parents and children requires some sacrifice on both sides to teach Christian patience and, therefore, it is a significant school of the Christian life". ${ }^{26}$ It is therefore obvious that he sought to encourageparents and children to cultivate mutual understanding while displaying self- restraint and selfsacrifice. However, he did not encourage permissiveness in the upbringing. Children need to understand their responsibilities, as well as the responsibilities of their parents, and adhere to them in their daily lives.

A ndrey Sheptytsky's idea about the benefit of spending time together with the family members is as relevant as ever. In the religious figure's interpretation, it is primarily concerned with praying together and reading religious books. He considered common prayer and common reading as a guarantee of peace and harmony in the family. ${ }^{27}$ Spending time together will eventually encourage family members to fulfill their obligations towards other people. It will also teach them to solve problems and work together, as well as to stand in solidarity with each other. It will therefore ensure a genuine understanding in all matters. ${ }^{28}$

In the context of modern labour migration of the population, many Ukrainianfamilies connect their fate with other countries. This problem is not new. There were several waves of migration and it is worth noting that during the $19^{\text {th }}$ and early $20^{\text {th }}$ century, a significant number of Ukrainians have created a powerful diaspora in North and South A merica, as well as some European countries, aftercrossing the ocean. A mong the prerequisites for emigration were difficult financial situation, political humiliation and national discrimination against Ukrainians. Metropolitan Andrey Sheptytsky acknowledged the dangers of this situation, being aware of the threat of assimilation of Ukrainians with the titular nations of their countries of settlement. Therefore, he addressed the parents of Ukrainian

${ }^{25}$ Pastyrśke poslannja jepyskopa Andreja do dukhovenstva ta virnykh Stanyslavivśkoji jeparkhiji «Khrystyjanśka rodyna» (2007). In Šeptyćkyj Andrej. Pastyrśki poslannja 1899-1914 rr. L'viv, Vydavnyctvo «ARTOS», vol. 1, p. 62.

${ }^{26}$ Protokoly zasidań Lvvivśkykh arkhijeparkhial'nykh soboriv 1940-1944 rr. Protokoly zasidań pidhotovčykh ta uročystykh sesij (2000). L'viv, «Misioner», p. 170.

27 Pastyrśke poslannja jepyskopa Andreja do dukhovenstva ta virnykh Stanyslavivśkoji jeparxiji

«Khrystyjanśka rodyna» (2007). In Šeptyćkyj Andrej. Pastyrśki poslannja 1899-1914 rr.

L'viv,Vydavnyctvo «ARTOS», vol. 1, p. 70. 
28 Pastyrśke poslannja Mytropolyta Andreja «Do poljakiv hreko-katolyćkoho obrjadu» (2007). In Šeptyćkyj Andrej. Pastyrśki poslannja 1899-1914 rr. L'viv, Vydavnyctvo «ARTOS», vol. 1,p. 502. 
youth in Canada and emphasized the need to cultivate religious and moral character in children, as well as national feelings, “...so that our people do not vanish in the foreign lands, but remain an adornment and glory of our homeland...". ${ }^{29}$ It is worth noting that, although the Ukrainian diaspora was created under difficult conditions and required the Ukrainians to fight for the maintainance of their national identity, it managed to preserve national values, language, culture, and eventually became an outpost of the struggle for freedom, statehood and national identity of Ukrainians who inhabited the ethnic Ukrainianlands.

Andrey Sheptytsky considered the socialists to be a significant threat to the Christian world. He criticized their desire to weaken family life. He believed that under the socialist system, families could altogether disappear, because parents would stop caring about their children, and care for the younger generation would rely on state caretakers. As a result, children would stop loving and honoring their parents. ${ }^{30}$ To some extent, the Metropolitan was right. He outlined his reasoning in 1902, and seventeen years later the People's Commissariat for Education has issued a circular which would read as follows: "Family education of children is now becoming civic, social...". 31 The reason for this situation is revealed, in particular, in the report of Ivanovsky to the department of preschool education: itis necessary to create such conditions of education in order to permanently eliminate the harmful influence of the family. The government's expectations ofthe children are to 0 high to be able to entrust their education to inherently harmful elements. Children are the property of the state, not the parents. ${ }^{32}$

Public education has accomplished the task of ideologizing the younger generation and it should be noted that the efforts of educators in this area have been quite successful. It is also important to point out that along with the supporters of the idea of removing children from the family, there were also theopponents of this idea, and the abovementioned initiatives were not fully implemented in Soviet Ukraine. Therefore, the family often became the center where the mother tongue, national customs, traditions and faith were preserved.

In conclusion, we can state that Andrey Sheptytsky's views on family education remain relevant to this day. Formulated in the context of neoThomism, these views can cause some objection among the modern people, however, we believe that in many respects they are not devoid of rational thought. In particular, he

29 Šeptyćkyj Andrej. (1911). Kanadyjskym rusynam. Žovkva, Pečatnja OO. Vasylyjan, p. 8.

30 Pastyrśke poslannja Mytropolyta Andreja do dukhovenstva i virnykh «O Papśkim juvileju» (2007). In Šeptyćkyj Andrej. Pastyrśki poslannja 1899-1914 rr. L'viv, Vydavnyctvo «ARTOS», vol. 1, pp. 447-449.

${ }^{31}$ Central'nyj deržavnyj arkhiv vyščykh orhaniv vlady i upravlinnja Ukrajiny, f. 166. op. 1, spr.199, arc. 84. 
32 Central’nyj deržavnyj arkhiv vyščykh orhaniv vlady i upravlinnja Ukrajiny, f. 166. op. 1, spr.

200, arc. 75 . 
regarded the organization of family life and upbringing from the point of view of democracy. He was clearly aware of the link between family status and the progress of society. He emphasized that marital love is the basis of harmony and happinessin the family. A ndrey Sheptytsky viewed family education in the context of his owntasks, content and methods. The ideas of creating an ethical atmosphere in which children will be raised, a positive example of parents, formation of a moral person, patriot of the motherland and a good citizen in the conditions of family education, democratization of upbringing, and spending as much time with family as possible as the key to a sincere understanding in different life situations, remain as relevant as ever. 